\title{
Ceratopteris richardii (C-Fern): a model for investigating adaptive modification of vascular plant cell walls
}

\author{
Olivier Leroux ${ }^{1,2}$, Sharon Eeckhout ${ }^{2}$, Ronald L. L. Viane ${ }^{2}$ and Zoë A. Popper ${ }^{1 *}$ \\ 'Botany and Plant Science and The Ryan Institute for Environmental, Marine and Energy Research, School of Natural Sciences, \\ National University of Ireland, Galway, Ireland \\ ${ }^{2}$ Department of Biology, Research Group Pteridology, Ghent University, Ghent, Belgium
}

\section{Edited by:}

Madelaine Elisabeth Bartlett, Brigham Young University, USA

\section{Reviewed by:}

A. Mark Settles, University of Florida, USA

Jo Ann Banks, Purdue University, USA

\section{${ }^{*}$ Correspondence:}

Zoë A. Popper, Botany and Plant Science and The Ryan Institute for Environmental, Marine and Energy Research, School of Natural Sciences, National University of Ireland, Galway, Ireland

e-mail:zoe.popper@nuigalway.ie
Plant cell walls are essential for most aspects of plant growth, development, and survival, including cell division, expansive cell growth, cell-cell communication, biomechanical properties, and stress responses. Therefore, characterizing cell wall diversity contributes to our overall understanding of plant evolution and development. Recent biochemical analyses, concomitantly with whole genome sequencing of plants located at pivotal points in plant phylogeny, have helped distinguish between homologous characters and those which might be more derived. Most plant lineages now have at least one fully sequenced representative and although genome sequences for fern species are in progress they are not yet available for this group. Ferns offer key advantages for the study of developmental processes leading to vascularisation and complex organs as well as the specific differences between diploid sporophyte tissues and haploid gametophyte tissues and the interplay between them. Ceratopteris richardii has been well investigated building a body of knowledge which combined with the genomic and biochemical information available for other plants will progress our understanding of wall diversity and its impact on evolution and development.

Keywords: plant cell wall, ferns, vascular plants, monoclonal antibodies, development, tissue-specificity, mannans

\section{INTRODUCTION}

Driven by an increased awareness of the impact of plant cell wall composition on environmental responses, and their commercial exploitation, as well as by curiosity, and facilitated by technological developments, cell wall diversity and evolution has increasingly become a major research focus in the last 5 years (Popper, 2008; Sarkar etal., 2009; Yin etal., 2009; Popper and Tuohy, 2010; Sørensen et al., 2010; Popper et al., 2011; Fangel et al., 2012). Cell walls are involved at every level of plant morphology, growth and development, and have changed during evolution (Popper and Fry, 2004; Sørensen et al., 2010; Popper et al., 2011; Fangel et al., 2012); the evolution of morpho-anatomical characters in particular rely on cell wall modification. Cell division, cell expansion and cell differentiation, which give rise to the generation of cell shape and plant form, are intrinsically cell wall processes (Szymanski and Cosgrove, 2009; Boudaoud, 2010). For example plant cell division necessitates coordinated synthesis and deposition of a new wall between the two daughter cells and turgor-driven cell expansion depends on wall relaxation mediated for example by enzymes, such as xyloglucan endotransglucosylase (Fry et al., 1992; Nishitani and Tominaga, 1992), or proteins, such as expansins (McQueen-Mason et al., 1992; McQueen-Mason and Cosgrove, 1995), whose presence and action is dependent on wall composition (Franková and Fry, 2011).

Although initially highlighted by biochemical analyses our understanding of the taxonomically-based diversity of plant and algal cell wall components and their biosynthesis has been revolutionized by the availability of sequenced plant genomes (Yin etal., 2009; Popper etal., 2011). There are currently around forty fully sequenced plant and algal genomes (Goodstein et al., 2012). However, in sharp contrast to the late nineteenth century pteridomania which endangered some species (Dyer et al., 2001) ferns (here delimited as the monilophytes which includes ferns, whisk ferns and horsetails) now receive comparatively less attention than many other plant groups and full sequences of fern genomes are, as yet, unavailable (Barker and Wolf, 2010). Cronk (2009) noted that early genome sequencing focussed heavily on angiosperms; perhaps unsurprisingly given their economic prominence. Recently the need for greater phylogenetic coverage has been recognized and, aided by technological advances, has led to the sequencing of representatives of algae and earlier diverged land plants with phylogenetic significance and possessing relatively small genomes including the green alga, Ostreococcus tauri (Derelle et al., 2006) and the spike moss, Selaginella moellendorffii (Banks et al., 2011). Despite being hampered by its exceptionally large genome size (Burleigh et al., 2012) at 150 times greater than that of Arabidopsis, the first gymnosperm genome, Norway spruce (Picea abies), was published earlier this year (Nystedt et al., 2013). Thus, the remaining gaps include sequenced genomes of a fern (Nakazato et al., 2006) and a hornwort (Cronk, 2009). Similarly to gymnosperms, ferns include plants of significant commercial, economic and ecological value such as the aquatic giant salvinia (Salvinia molesta) that was recently added to the International Union for Conservation of Nature (IUCN) worst invasive alien species list (Luque et al., 2013). Ferns have a worldwide distribution and are adapted to diverse habitats; often occurring as pioneer 
species and occasionally becoming ecologically dominant e.g., Pteridium aquilinum (commonly known as bracken). Additionally, although ferns consist of $\sim 15,000$ species and therefore comprise only around $3 \%$ of vascular plant diversity globally (Schuettpelz and Pryer, 2008) they may account for up to $20 \%$ of vascular plant diversity in areas such as the West Indies (Groombridge, 1992).

Given the ecological importance and placement of ferns as early diverging euphyllophytes (a sub-division of vascular plants including monilophytes and seed plants) a better understanding of their cell wall complexity, in terms of composition, biosynthesis and tissue- and cell-specific variation, may provide novel insight into key developmental processes, for example vascularisation of leaves (Cronk, 2009), as well as providing unique opportunity to investigate gametophyte-specific processes. In this perspective we review the current state of knowledge regarding fern cell wall composition, the impact of genome sequencing on our understanding of evolutionary pathways of cell wall biosynthetic genes, the requirement for a sequenced fern genome and how this might impact future research focussed on plant cell wall biology, physiology, evolution and development.

\section{FERN CELL WALLS}

Biochemical analyses have contributed much of what we know about fern cell walls and indicate that they are compositionally similar, though not identical, to those of flowering plants. More specifically, mannose-containing polysaccharides such as mannan and glucomannan appear to be abundant in ferns, whereas pectins appear to be present in lower concentrations than found in other plants (Popper and Fry, 2004; Silva et al., 2011). On the other hand, some wall components have a structure and function which appears to pre-date the divergence of ferns from gymnosperms and flowering plants. $\alpha$-Expansins, wall-acting proteins which mediate acid-induced wall creep (McQueen-Mason et al., 1992; McQueen-Mason and Cosgrove, 1995), have not only been identified from the ferns Marsilea quadrifolia and Regnellidium diphyllum (both species of aquatic ferns) by their homology to flowering plant $\alpha$-expansins but protein extracts from M. quadrifolia are capable of inducing wall creep in cucumber cell walls (Kim et al., 2000). The importance of cell wall composition and metabolism to plants environmental responses and survival, as well as our exploitation of them, deem wall composition worthy of extensive exploration. Current approaches include application of specific cell wall-directed tools and methodologies (Fry, 2000; Popper, 2011) including carbohydrate microarrays (Moller et al., 2007), glycome profiling (Pattathil et al., 2012) and microscopy utilizing wall-directed monoclonal antibodies (mAbs), as exemplified in Figure 1 (right hand side), and carbohydrate-binding modules (CBMs; Sørensen et al., 2009; Pattathil et al., 2010; Hervé et al., 2011) as well as comparative genome analysis.

\section{THE LYCOPHYTE-EUPHYLLOPHYTE DIVIDE}

The genes responsible for the biosynthesis of plant cell wall components are increasingly well identified and characterized. However, the genes responsible for the synthesis and metabolism of some components are not yet fully elucidated (Harholt et al., 2012). This is particularly true for seemingly anomalous occurrences of specific wall components. For instance, although cellulose synthase-like (CSL) supergene family members CslF's and CslH's are responsible for synthesizing $\beta$ - $(1,3)(1,4)$-glucan (mixed linkage glucan, MLG) in members of the Poales (grasses; Richmond and Somerville, 2000; Burton et al., 2006, 2008; Doblin et al., 2009) the absence of orthologues of these genes (Harholt et al., 2012) confounds detection of MLG in Selaginella moellendorffii and synthesis of MLG in this plant remains enigmatic but is corroborated by the discovery of MLG in Equisetum (horsetails; Fry et al., 2008; Sørensen et al., 2008).

Sequencing and genome analysis of the whisk fern Selaginella moellendorffii, chosen for its small genome size (Banks et al., 2011; Harholt et al., 2012), has already proven invaluable to elucidating diversification of cell wall components and their biosynthetic machinery (Popper et al., 2011). Lycophytes are the earliest diverging extant plants to have a vascular system and a dominant sporophyte generation. However, disparities in genome sequence and cell wall biochemistry between Selaginella and other sequenced vascular plants including Arabidopsis (Arabidopsis Genome Initiative, 2000), Populus (Tuskan et al., 2006), and the grasses, rice (International Rice Sequencing Project, 2005), and Brachypodium (International Brachypodium Initiative, 2010), detailed below, highlight the need for fern sequences and detailed cell wall studies, not only to help better understand ferns, but also euphyllophyte evolution and development.

Although the majority of cell wall components found in flowering plants also occur in Selaginella, Harholt et al. (2012) observed differences in the abundance, localization and extractability between wall polymers in flowering plants compared with those in Selaginella. This is potentially indicative of differences in interactions between specific cell wall components. Pectins in particular appeared to not only be more abundant in lycophytes than in angiosperms but also required harsher extraction procedures (Harholt et al., 2012). The pectin, rhamnogalacturonan II, was found to occur in all vascular plant groups in similar concentration but, despite appearing to be highly conserved, exhibited a minor compositional variance; in lycophytes, ferns and whisk ferns; a rhamnose residue was replaced by a 3-O-methyl rhamnose residue in one of the side chains (Matsunaga et al., 2004). Furthermore, some cell wall features appear to have arisen through convergent evolution. For example the regulation and biosynthesis of syringyl (S) lignin which reinforces the secondary cell walls in the vascular tissue of flowering plants and lycophytes, but is absent from the majority of ferns and gymnosperms, occur via independent pathways (Weng et al., 2008, 2011; Zhao et al., 2010; Novo-Uzal et al., 2012). In angiosperms $S$ lignin is synthesized from guaiacyl lignin intermediates by ferulic acid/coniferaldehyde/coniferyl alcohol 5-hydroxylase (F5H) and although Selaginella moellendorffii contains a functional $\mathrm{F} 5 \mathrm{H}$ it is not orthologous to angiosperm $\mathrm{F} 5 \mathrm{Hs}$ instead belonging to a clade of genes unique to Selaginella (Weng et al., 2008). As Harholt et al. (2012) point out this is in direct contrast with an apparent lack of diversification and specialization within the cellulase synthase (CESA) superfamily. Homologs of IRX10, also involved in vascular formation in land plants, were found in the moss Physcomitrella patens and were recently reported to exhibit functional conservation with those from Arabidopsis (Hörnblad et al., 2013). Taken together these data suggest that at least some components of vascular tissues considered to be a 


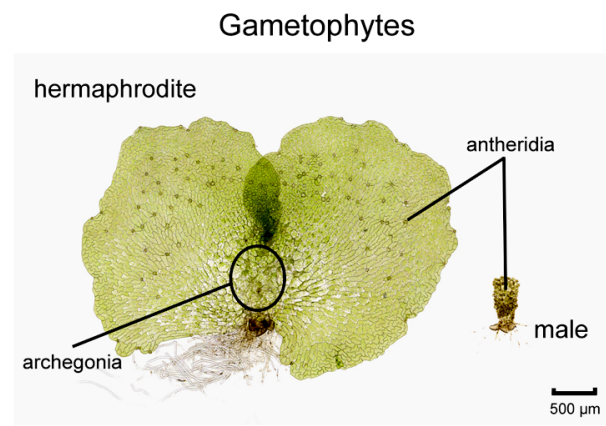

Sporophytes

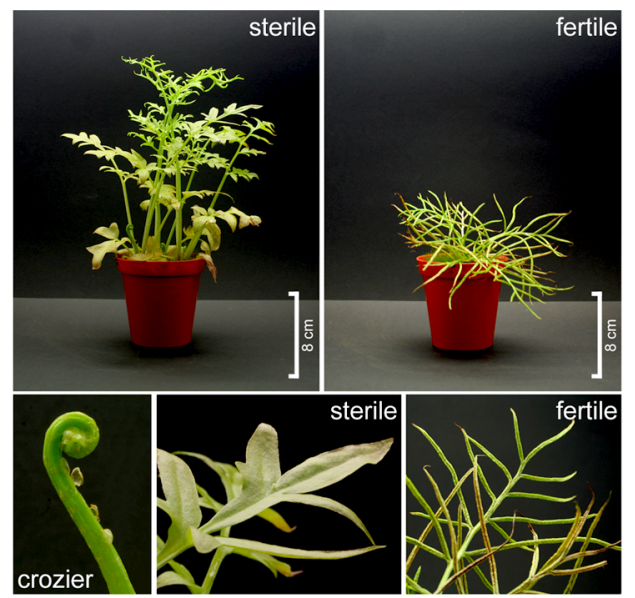

FIGURE 1 | Ceratopteris richardii morphology (left hand side).

Gametophytes develop as hermaphrodites or males. Sporophyte fronds are dimorphic. Fronds are initially sterile and oval shaped to three-lobed but new fronds become progressively larger and more pinnately dissected. Fertile fronds are more finely dissected and their enrolled margins are covering the sporangia. Developmental and tissue-specific variation in Ceratopteris richardii cell walls (right hand side). Localization of cell wall components in

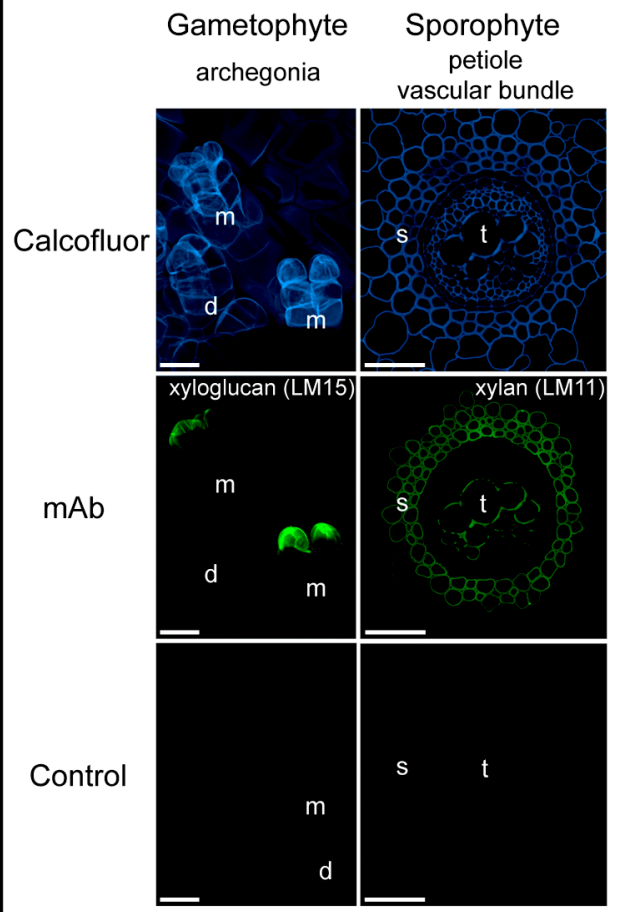

hermaphroditic gametophytes and in transverse sections of sporophytic petioles. Calcofluor white stains $\beta$-glucans such as cellulose, which occurs in most cell walls. A xyloglucan epitope (mAb LM15) is detected in the apical neck cells of fully mature (and opened) archegonia. LM11, a mAb directed against xylan labeled secondary cell walls of the petiole. $d$, developing archegonium; m, mature and opened archegonia; mAb, monoclonal antibody; $\mathrm{s}$, sclerenchyma; $\mathrm{t}$, tracheids. Scale bars $=20 \mu \mathrm{m}$. "hallmark" of vascular plants (Weng et al., 2008), are not homologous between the lycophyte and euphyllophyte vascular plant lineages. Lycophytes also have unique primary cell wall characters. The isolation of uniquely high concentrations of the unusual sugar residue 3-O-methyl-D-galactose had previously been considered an autapomorphy of the lycophytes as its occurrence was restricted to homosporous (including Lycopodium pinifolium, Huperzia selago, and Diphasiatrum alpinum) and heterosporous lycophyte (including three species of Selaginella although not $S$. moellendorffii) primary cell walls (Popper et al., 2001).

Despite accounting for only $5-10 \%$ of the dry mass of cell walls (Jamet et al., 2008) proteins are intrinsically responsible for wall synthesis, structure and function, primarily through their modification of other cell wall components, such as polysaccharides, in response to developmental and environmental cues. There appears to be a phylogenetic basis to the profile of cell wall-acting enzymes possessed by a specific plant. While some enzyme activities, such as xyloglucan endotransglucosylase, which coordinates expansive plant cell growth by cutting and rejoining of intermicrofibrillar xyloglucan chains (Fry et al., 1992; Nishitani and Tominaga, 1992), appear to be present in all vascular plants (Vissenberg etal., 2003) others show a disjuncture between lycophytes and euphyllophytes. Franková and Fry (2011) extracted and assayed proteins from 57 rapidly growing plant organs from a range of flowering plants, Selaginella (apoda), a horsetail and a liverwort and found remarkable differences in glycanase (endo-hydrolase) and glycosidase (exo-hydrolase) activities which correlated with differences in wall composition. For instance, $\beta$-mannosidase activities were highest in plants with mannan-rich endosperms requiring rapid metabolism during germination rather than in plants, including Selaginella, whose vegetative tissues have mannan-rich cell walls (Franková and Fry, 2011). Polygalacturonases (PGs) are a large family of hydrolytic enzymes (Kim et al., 2006) which modify pectins developmentally. Analysis of Arabidopsis, Populus, rice, Selaginella, and Physcomitrella genomes indicate an expansion of the PG gene family occurred after the divergence of the lycophytes and euphyllophytes; 16 PG genes were identified in the lycophyte Selaginella in comparison with 44 in rice and 75 in Populus (Yang et al., 2013). Although lycophytes and euphyllophytes have shared characteristics including vascular tissue and a dominant 
sporophyte generation they last shared a common ancestor 400 million years ago (Pryer et al., 2004) and there are many differences as summarized in Table 1. A fundamental difference between the groups is that lycophytes possess microphylls whereas euphyllophytes possess structurally more complex, particularly with respect to vascularisation, megaphyll leaves (Cronk, 2009). The two organs appear to be developmentally and morphologically distinct which, in combination with the existence of many leafless but otherwise highly complex fossils, has led to relative consensus that despite having similar functional roles microphylls and megaphylls are not homologous (Cronk, 2009). Yang et al. (2013) hypothesized that expansion of the PG gene family may be correlated with the evolution of leaves and increased organ complexity but emphasized that the current sample of sequenced vascular plant genomes, which does not yet include ferns, does not enable dating of the PG gene family expansion. However, spatialtemporal changes in remodeling of cell wall components, such as pectins by $\mathrm{PGs}$, lead to changes in wall biomechanical properties, resulting in altered development and morphology (Boudaoud, 2010).

As outlined above the distinct differences in cell wall biochemistry between lycophytes and euphyllophytes is perhaps not unexpected because lycophytes are distinguished as a sister group to all other vascular plants with associated key differences in anatomy and development (Judd et al., 1999; Pryer et al., 2001; Banks, 2009). Therefore, a model fern may provide key insight into whole plant development (Tilney et al., 1990; Racusen, 2002) and the impact of cell wall metabolism.

\section{C-Fern CELL WALLS}

A strong foundation for using Ceratopteris richardii, often referred to as C-Fern, as a model to investigate the influence of cell walls on development has been laid by anatomical and cytochemical investigations. Such studies include scanning electron microscopy of xylem (Carlquist and Schneider, 2000), gametophyte development (Banks, 1999), embryogenesis (Johnson and Renzaglia, 2008), the histology of spermatocyte cell wall composition (Cave and Bell, 1973) and drug-induced perturbation of cellulose synthesis in root hairs (Meekes, 1986). The latter study indicated that C-Fern responds to cell wall-acting drugs in a similar way to flowering plants. Additionally C-Fern is highly sensitive and provides opportunity to investigate drug action; in a single cell layer, in free-living haploid tissues (gametophytes), and in combination with microtubule organizing centers which might be important in order to investigate the effects of microtubule disruption on cell wall component secretion (Meekes, 1986). Furthermore, an array of C-Fern mutants exists including some that may have altered cell walls. One of the most striking is polka dot, which has clumped chloroplasts, putatively resulting from disruption to the cytoskeleton (Vaughn et al., 1990), which may have led to the observed associated weaknesses in spore walls.

Table 1 | Summary of differences between the lycophyte Selaginella moellendorffii, fern Ceratopteris richardii, and angiosperms

\begin{tabular}{|c|c|c|c|}
\hline Character & Selaginella moellendorffii & Ceratopteris richardii & Flowering plants \\
\hline Taxonomic grouping & Lycophyte & Fern & Angiosperms \\
\hline Ploidy of sporophytes & Diploid & Diploid & Various \\
\hline Dominant generation & Sporophyte & Sporophyte & Sporophyte \\
\hline Gametophytes & $\begin{array}{l}\text { Endosporic (remain largely enclosed in } \\
\text { spore tissue), subterranean }\end{array}$ & Exosporic and photosynthetic & $\begin{array}{l}\text { Endosporic (remain enclosed in } \\
\text { sporophyte tissues) }\end{array}$ \\
\hline $\begin{array}{l}\text { Primary photosynthetic } \\
\text { organ }\end{array}$ & $\begin{array}{l}\text { Microphylls, typically with only a single } \\
\text { unbranched vascular strand }\end{array}$ & $\begin{array}{l}\text { Megaphylls (euphylls), lateral } \\
\text { organs of the shoot, derived from } \\
\text { stems and possessing branched } \\
\text { vasculature }\end{array}$ & Megaphylls (euphylls) \\
\hline Plant axis & $\begin{array}{l}\text { Rhizophore, homorhizic roots (which } \\
\text { develop laterally relative to the } \\
\text { embryonic axis of the embryo), and } \\
\text { stem }\end{array}$ & Homorhizic roots, and stem & $\begin{array}{l}\text { Allorhizic roots (which develop at } \\
\text { the opposite end of the embry- } \\
\text { onic axis to the shoots (eudi- } \\
\text { cots), or a secondarily homorhizic } \\
\text { root system (most monocotyle- } \\
\text { donous plants), and stem }\end{array}$ \\
\hline Mega- and micro-sporangia & $\begin{array}{l}\text { Heterosporous, typically producing four } \\
\text { megaspores in the megasporangium } \\
\text { and hundreds of micro-spores in the } \\
\text { micro-sporangium }\end{array}$ & $\begin{array}{l}\text { Homosporous, producing } \\
\text { hermaphrodite and male } \\
\text { gametophytes }\end{array}$ & $\begin{array}{l}\text { Heterosporous, producing a dis- } \\
\text { persed ovule (mega-sporangium } \\
\text { protected by an integument) }\end{array}$ \\
\hline Branching pattern & $\begin{array}{l}\text { Dichotomous (derived from } \\
\text { dichotomous branching of the shoot } \\
\text { apical meristems) }\end{array}$ & Lateral & Lateral \\
\hline
\end{tabular}




\section{C-Fern AS A MODEL PLANT}

Clearly, as previously voiced by others (Weng etal., 2008; Cronk, 2009), there is a requirement for sequenced fern genomes. Although there are currently no fully sequenced fern genomes the National Center for Biotechnology Information's (NCBI) short read archive (SRA) database has incomplete genome data for two ferns, Ceratopteris richardii and, the perhaps more universally familiar invasive, Pteridium aquilinum (http://www.ncbi.nlm.nih.gov/). The Pteridium sequence is derived from a gametophyte transcriptome (Der et al., 2011) similarly the C-Fern expressed sequenced tags (ESTs) are from the early stages of development in germinating spores (Salmi et al., 2005); both sequences are therefore equivalent to the tissues which give rise to pollen grains and embryo sacs in flowering plants. Curiously although wall synthesis and restructuring are required for gametophyte development, particularly cell division and expansive cell growth, less than $1 \%$ of the gene products expressed in Ceratopteris spores are cell wall-localized (Salmi et al., 2005). Since annotation was carried out by BLAST comparison with the Arabidopsis genome one possibility is that fern and flowering plant cell wall-localized genes are significantly divergent.

Leptosporangiate ferns, of which Ceratopteris richardii and Pteridium aquilinum are members, comprise over $95 \%$ of extant fern diversity (Schuettpelz and Pryer, 2008). In fact both of the aforementioned species belong to the polypods, a clade strongly supported by molecular and morphological characters including sporangia which possess a vertical annulus interrupted by the stalk (Pryer etal., 2001; Schuettpelz and Pryer, 2008). However, whereas Pteridium is placed in the small dennstaedtioid clade, Ceratopteris belongs to the large, diverse pteridoid clade which accounts for about $10 \%$ of extant fern diversity (Schneider et al., 2004; Schuettpelz and Pryer, 2008); this suggests that Ceratopteris is likely to be highly representative of other ferns. Ceratopteris is homosporous and produces hermaphrodite and male gametophytes (see Figure 1). The male gametophytes are produced in response to antheridiogen (Schedlbauer and Klekowski, 1972). The diploid sporophytes are extremely heteroblastic, initially producing entire sterile leaves and progressing to highly dissected fertile leaves which, under culture conditions, produce many spores continuously throughout the year within sporangia on their enrolled leaf margins (Hickok et al., 1987; Figure 1, left hand side). In comparison to many other ferns including Pteridium, Ceratopteris sporophytes are relatively small, reaching $30-40 \mathrm{~cm}$ in height. This feature particularly coupled with its ease of growth in culture has been responsible for the widespread application of Ceratopteris as model in undergraduate plant biology teaching, for example to demonstrate plant lifecycles, genetics and development, and in research laboratories (Hickok et al., 1987, 1998; Calie, 2005; Spiro and Knisely, 2008). This has lead to the development of specific tools and techniques including mutant generation, selection and characterization; mutants include abscisic acid (Hickok, 1985), herbicide-tolerant (Hickok and Schwarz, 1986) and salt-tolerant (Warne etal., 1995). Other features which make Ceratopteris a suitable model include: (1) a short sexual life cycle which can be completed in under 120 days, (2) continuous and abundant spore production, (3) spores that can be stored and remain viable for many years, (4) gametophytes which can be self-fertilized to generate completely homozygous sporophytes, (5) visible microtubule organizing centers and developmental synchrony of cells within a single gametophyte (Hoffman and Vaughn, 1995), (6) sporophytes that can be vegetatively propagated from marginal leaf buds or gemmae allowing maintenance of even sterile mutants (Hickok et al., 1987) and (7) amenability to mutagenesis. Furthermore, although experiments initially suggested that Ceratopteris is resistant to Agrobacterium-mediated transformation (Hickok et al., 1987) Agrobacterium has now been shown capable of transforming Ceratopteris thalictroides (and Chinese brake fern, Pteris vittata) spores leading to stably transformed plants; inheritance analyses revealed stable expression of the transgene in second generation sporophytes (Muthukumar etal., 2013). Additionally, Ceratopteris gametophytes have been shown to take up DNA and RNA directly enabling elucidation of gene function through observation of phenotype following targeted silencing (Stout et al., 2003; Kawai-Toyooka et al., 2004; Rutherford et al., 2004).

\section{LOCATION, LOCATION, LOCATION AND FUTURE PERSPECTIVE}

Although a fully sequenced fern genome will be available in the near future, likely contributing much to our understanding of the evolution of euphyllophytes, plant cell wall components and their biosynthesis, it is unlikely to reveal the full story. The reason for this is that many wall components are deposited in a tissue, cellular or even sub-cellular fashion, often in response to development (Leroux et al., 2007, 2011). Therefore, genomic studies will yield most information when carried out in combination with localization of wall components using (immuno)cytochemical methods (Cave and Bell, 1973; Hervé et al., 2011). Many of the mAbs and CBMs developed to flowering plant cell walls have the ability to recognize and bind to epitopes present in bryophyte (Carafa et al., 2005) and fern (Leroux et al., 2007, 2011) cell walls including those of C-Fern (as exemplified by Figure 1). The ability to apply these techniques to Ceratopteris (and other ferns) provides advantages for investigating plant development involving the cell wall, not afforded by earlier diverging vascular plants. For example Selaginella gametophytes are endosporic, meaning that the female gametophyte remains enshrouded in spore tissue, and subterranean. Flowering plant gametophytes are similarly embedded in sporophyte tissues. In contrast fern gametophytes which are photosynthetic and free-living can be prepared (relatively) easily for biochemical analysis. Furthermore, it is possible to follow every cell throughout development. A fern model, such as Ceratopteris, once sequenced will build on what has already been uncovered by investigation of other sequenced plants, particularly other vascular plants such as Selaginella, and likely divulge many secrets relating to euphyllophyte cell wall biochemistry, evolution and function.

\section{ACKNOWLEDGMENTS}

Olivier Leroux is supported by an IRCSET EMPOWER award (PD/2011/2326). A grant from Research Foundation - Flanders, Belgium (F.W.O. - Vlaanderen; Research stay K209012N) supported Sharon Eeckhout during a research visit to NUI Galway (June 2012). 


\section{REFERENCES}

Arabidopsis Genome Initiative. (2000). Analysis of the genome sequence of the flowering plant Arabidopsis thaliana. Nature 408, 796-815. doi: 10.1038/35048692

Banks, J. A. (1999). Gametophyte development in ferns. Annu. Rev. Plant Physiol. Plant Mol. Biol. 50, 163-186. doi: 10.1146/annurev. arplant.50.1.163

Banks, J. A. (2009). Selaginella and 400 million years of separation. Annu. Rev. Plant Biol. 60, 223-238. doi: 10.1146/annurev. arplant.59.032607.092851

Banks, J. A., Nishiyama, T., Hasebe, M., Bowman, J. L., Gribskov, M., dePamphilis, C., et al. (2011). The Selaginella genome identifies genetic changes associated with the evolution of vascular plants. Science 20, 960963. doi: 10.1126/science. 1203810

Barker, M. S., and Wolf, P. G. (2010). Unfurling fern biology in the genomics age. Bioscience 60, 177-185. doi: 10.1525/bio.2010.60.3.4

Boudaoud, A. (2010). An introduction to the mechanics of morphogenesis for plant biologists. Trends Plant Sci. 15, 353-360. doi: 10.1016/j.tplants.2010.04.002

Burleigh, J. G., Barbazuk, W. B., Davis, J. M., Morse, A. M., and Soltis, P. S. (2012). Exploring diversification and genome size evolution in extant gymnosperms through phylogenetic synthesis. J. Bot. 2012, 292857. doi:10.11155/2012/292857

Burton, R. A., Jobling, S. A., Harvey, A. J., Shirley, N. J., Mather, D. E., Bacic, A., et al. (2008). The genetics and transcriptional profiles of the cellulose synthase-like HvCslF gene family in barley (Hordeum vulgare L.). Plant Physiol. 146, 1821-1833. doi: 10.1104/pp.107.114694

Burton, R. A., Wilson, S. M., Hrmova, M., Harvey, A. J., Shirley, N. J., Medhurst, A., et al. (2006). Cellulose synthase-like CslF genes mediate the synthesis of cell wall $(1,3 ; 1,4)-\beta-D-$ glucans. Science 311, 1940-1942. doi: $10.1126 /$ science. 1122975

Calie, P. J. (2005). A mutant hunt using the C-Fern (Ceratopteris richardii). Am. Biol. Teach. 67, 295-299. doi: 10.1662/0002-7685 (2005)067[0295:AMHUTC]2.0.CO;2 Carafa, A., Duckett, J. G., Knox, J. P., and Ligrone, R. (2005). Distribution of cell wall xylans in bryophytes and tracheophytes: new insights into basal interrelationships of land plants. New. Phytol. 168, 231-240. doi: 10.1111/j.1469-8137.2005.01483.x

Carlquist, S., and Schneider, E. L. (2000). SEM studies of vessels in ferns 14. Ceratopteris. Aquat. Bot. 66, 1-8. doi: 10.1016/S0304-3770(99) 00023-6

Cave, C. F., and Bell, P. R. (1973). The cytochemistry of the walls of the spermatocytes of Ceratopteris thalictroides. Planta 109, 99-104. doi: 10.1007/BF00386117

Cronk, Q. C. B. (2009). The Molecular Organography of Plants. (Oxford: Oxford University Press).

Der, J. P., Barker, M. S., Wickett, N. J., dePamphilis, C. W., and Wolf, P. G. (2011). De novo characterization of the gametophyte transcriptome in bracken fern, Pteridium aquilinum. BMC Genomics 12:99. doi: 10.1186/1471-216412-99

Derelle, E., Ferraz, C., Rombauts, S., Rouzé, P., Worden, A. Z., Robbens, S., et al. (2006). Genome analysis of the smallest free-living eukaryote Ostreococcus tauri unveils many unique features. Proc. Natl. Acad. Sci. U.S.A. 103, 11647-11652. doi: 10.1073/pnas.0604795103

Doblin, M. S., Pettolino, F. A., Wilson, S. M., Campbell, R., Burton, R. A., Fincher, G. B., et al. (2009). A barley cellulose synthase-like CSLH gene mediates $(1,3 ; 1,4)$ - $\beta$-D-glucan synthesis in transgenic Arabidopsis. Proc Natl. Acad. Sci. U.S.A. 14, 5996-6001. doi: 10.1073/pnas.0902019106

Dyer, A., Lindsay, S., and Lusby, P. (2001). The fall and rise of the Oblong Woodsia in Britain. Bot. J. Scotl. 53, 107-120. doi: 10.1080/ 03746600108685017

Fangel, J. U., Ulvskov, P., Knox, J. P., Mikkelsen, M. D., Harholt, J., Popper, Z. A., et al. (2012). Cell wall evolution and diversity. Front. Plant Sci. 3:152. doi: 10.3389/fpls.2012. 00152

Franková, L., and Fry, S. C. (2011). Phylogenetic variation in glycosidases and glycanases acting on plant cell wall polysaccharides, and the detection of transglycosidase and trans- $\beta$-xylanase activities. Plant $J$. 67, 662-681. doi: 10.1111/j.1365313X.2011.04625.x

Fry, S. C. (2000). The Growing Plant Cell Wall: Chemical and Metabolic Analysis, Reprint Edn. (Caldwell: The Blackburn Press).

Fry, S. C., Nesselrode, B. H., Miller, J. G., and Mewburn, B. R. (2008). Mixedlinkage $(1 \rightarrow 3,1 \rightarrow 4)-\beta$-D-glucan is a major hemicellulose of Equisetum (horsetail) cell walls. New Phytol. 179, 104-115. doi: 10.1111/j.14698137.2008.02435.x

Fry, S. C., Smith, R. C., Renwick, K. F., Martin, D. J., Hodge, S. K., and Matthews, K. J. (1992).
Xyloglucan endotransglycosylase, a new wall-loosening enzyme activity from plants. Biochem. J. 282, 821828.

Goodstein, D. M., Shu, S., Howson, R., Neupane, R., Hayes, R. D. Fazo, J., et al. (2012). Phytozome: a comparative platform for green plant genomics. Nucleic Acids Res. 40, 1178-1186. doi: 10.1093/nar/gkr 944

Groombridge, B. (1992). Global Biodiversity. Status of the Earth's Living Resources. (London: Chapman and Hall).

Harholt, J., Sørensen, I., Fangel, J., Roberts, A., Willats, W. G. T., Scheller, H. V., et al. (2012). The glycosyltransferase repertoire of the spikemoss Selaginella moellendorffii and a comparative study of its cell wall. PLoS ONE 7:e35846. doi:10.1371/journal.pone.0035846

Hervé, C., Marcus, S. E., and Knox, J. P. (2011). "Monoclonal antibodies, carbohydrate-binding modules, and the detection of polysaccharides in plant cell walls," in The Plant Cell Wall: Methods and Protocols. Methods in Molecular Biology, Vol. 715, ed. Z. A. Popper (New York: Springer), 103-114.

Hickok, L. G. (1985). Abscisic acid resistant mutants in the fern Ceratopteris: characterisation and genetic analysis. Can. J. Bot. 63, 1582-1585. doi: 10.1139/b85-220

Hickok, L. G., Warne, T. R., Baxter, S. L., and Melear, C. T. (1998). Sex and the C-Fern: not just another life cycle. Bioscience 48, 1031-1037. doi: 10.2307/1313459

Hickok, L. G., Warne, T. R., and Slocum, M. K. (1987). Ceratopteris richardii: applications for experimental plant biology. Am. J. Bot. 74, 1304-1316. doi: $10.2307 / 2444165$

Hickok, L. G., and Schwarz, O. J. (1986). An in vitro whole plant selection system: selection for paraquat tolerance in the fern Ceratopteris. Theor. Appl. Genet. 72, 302-306. doi 10.1007/BF00288565

Hoffman, J. C., and Vaughn, K. C. (1995). Using the developing spermatogenous cells of Ceratopteris to unlock the mysteries of the plant cytoskeleton. Int. J. Plant Sci. 156 346-358. doi: 10.1086/297256

Hörnblad, E., Ulfstedt, M., Ronne, H., and Marchant, A. (2013). Partial functional conservation of IRX10 homologs in Physcomitrella paten and Arabidopsis thaliana indicates an evolutionary step contributing to vascular formation in land plants. $B M C$ Plant Biol. 13:3. doi: 10.1186/14712229-13-3
International Brachypodium Initiative. (2010). Genome sequencing and analysis of the model grass Brachypodium distachyon. Nature 408, 796815. doi: $10.1038 / 35048692$

International Rice Sequencing Project. (2005). The map-based sequence of the rice genome. Nature 436, 793800. doi: $10.1038 /$ nature 03895

Jamet, E., Albenne, C., Boudart, G., Irshad, M., Canut, H., and Pont-Lezica, R. (2008). Recent advances in plant cell wall proteomics. Proteomics 8, 893-908. doi: 10.1002/pmic. 200700938

Johnson, G. P., and Renzaglia, K. S. (2008). Embryology of Ceratopteris richardii (Pteridaceae, tribe Ceratopteridae), with emphasis on placental development. J. Plant Res. 121, 581-592. doi: 10.1007/s10265-0080187-3

Judd, W. S., Campbell, C. S., Kellogg, E. A., and Stevens, P. F. (1999). Plant Systematics. A Phylogenetic Approach. (Sunderland, USA: Sinauer Associates, Inc.).

Kawai-Toyooka, H., Kuramoto, C., Orui, K., Motoyama, K., Kikuchi, K., Kanegae, T., et al. (2004). DNA interference: a simple and efficient genesilencing system for high-throughput functional analysis in the fern Adiantum. Plant Cell Physiol. 45, 16481657. doi: $10.1093 /$ pcp/pch186

Kim, J., Shiu, S. H., Thoma, S., Li, W. H., and Patterson, S. E. (2006). Patterns of expansion and expression divergence in the plant polygalacturonase gene family. Genome Biol. 7, 87. doi: 10.1186/gb-2006-7-9-r87

Kim, J. H., Cho, H.-T., and Kende, H. (2000). $\alpha$-Expansins in the semiaquatic ferns Marsilea quadrifolia and Regnellidium diphyllum: evolutionary aspects and physiological role in rachis elongation. Planta 212, 85-92. doi: 10.1007/s004250000367

Leroux, O., Knox, J. P., Leroux, F., Vrijdaghs, A., Bellefroid, E., Borgonie, G., et al. (2007). Intercellular pectic protuberances in Asplenium: new data on their composition and origin. Ann. Bot. 100, 1165-1173. doi: $10.1093 / \mathrm{aob} / \mathrm{mcm} 210$

Leroux, O., Leroux, F., BagniewskaZadworna, A., Knox, J. P., Claeys, M., Bals, S., etal. (2011). Ultrastructure and composition of cell wall appositions in the walls of Asplenium (Polypodiales). Micron 42, 863-870. doi: 10.1016/j.micron. 2011.06.002

Luque, G. M., Bellard, C., Bertelmeier, C., Bonnaud, E., Genovesi, P., Simberloff, D., et al. (2013). Monster fern makes IUCN invader list. Nature 498, 37. doi: 10.1038/498037a 
Matsunaga, T., Ishii, T., Matsumoto, S., Higuchi, M., Darvill, A., Albersheim, P., et al. (2004). Occurrence of the primary cell wall polysaccharide rhamnogalacturonan II in Pteridophytes, Lycophytes, and Bryophytes. Implications for the evolution of vascular plants. Plant Physiol. 134, 339 351. doi: 10.1104/pp.103.030072

McQueen-Mason, S., and Cosgrove, D. J. (1995). Expansin mode of action on cell walls: analysis of wall hydrolysis, stress relaxation, and binding. Plant Physiol. 107, 87-100.

McQueen-Mason, S. J., Durachko, D. M., and Cosgrove, D. J. (1992). Two endogenous proteins that induce cell wall extension in plants. Plant Cell 4, 1425-1433.

Meekes, H. T. H. M. (1986). Inhibition and recovery of cell wall formation in root hairs of Ceratopteris thalictroides. J. Exp. Bot. 37, 1201-1210. doi: 10.1093/jxb/37.8.1201

Moller, I., Sørensen, I., Bernal, A. J., Blaukopf, C., Lee, K., Øbro, J., et al. (2007). High-throughput mapping of cell wall polymers within and between plants using novel microarrays. Plant J. 50, 1118-1128. doi: 10.1111/j.1365-313X.2007.03114.x

Muthukumar, B., Joyce, B. L., Elless, M. P., and Stewart, C. N. Jr. (2013). Stable transformation of ferns using spores as targets: Pteris vittata (Chinese brake fern) and Ceratopteris thalictroides (C-Fern 'Express'). Plant Physiol. doi: 10.1104/pp.113.224675 [Epub ahead of print].

Nakazato, T., Jung, M. K., Housworth, E. A., Riesberg, L. H., and Gastony, G. J. (2006). Genetic map-based analysis of the genome structure in the homosporous fern Ceratopteris richardii. Genetics 173, 1585-1597. doi: 10.1534/genetics.106.055624

Nishitani, K., and Tominaga, R. (1992). Endo-xyloglucan transferase, a novel class of glycosyl transferase that catalyzes transfer of a segment of xyloglucan molecule to another xyloglucan molecule. J. Biol. Chem. 267, 21058-21064.

Novo-Uzal, E., Pomar, F., Gómez Ros, L. V., Espiñeira, J. M., and Ros Barceló, A. (2012). Evolutionary history of lignins. Adv. Bot. Res. 61, 312-350. doi: 10.1016/B978-0-12416023-1.00009-4

Nystedt, B., Street, N. R., Wetterbom, A., Zuccolo, A., Lin, Y.-C., Scofield, D. G., et al. (2013). The Norway spruce genome sequence and conifer genome evolution. Nature 497, 579584. doi: 10.1038/nature12211

Pattathil, S., Avci, U., Baldwin, D., Swennes, A. G., McGill, J. A., Popper, Z., et al. (2010).
A comprehensive toolkit of plant cell wall glycan-directed monoclonal antibodies. Plant Physiol. 153, 514525. doi: 10.1104/pp.109.151985

Pattathil, S., Avci, U., Miller, J. S., and Hahn, M. G. (2012). “Immunological approaches to plant cell wall biomass characterization: glycome profiling," in Biomass Conversion: Methods and Protocols. Methods in Molecular Biology, Vol. 908, ed. M. E. Himmel (New York: Springer), 61-72.

Popper, Z. A. (2008). Evolution and diversity of green plant cell walls. Curr. Opin. Plant Biol. 11, 286-292. doi: 10.1016/j.pbi.2008.02.012

Popper, Z. A. (2011). "Extraction and detection of arabinogalactan proteins," in The Plant Cell Wall: Methods and Protocols. Methods in Molecular Biology, Vol. 715, ed. Z. A. Popper (New York: Springer).

Popper, Z. A., and Fry, S. C. (2004) Primary cell wall composition of pteridophytes and spermatophytes. New Phytol. 164, 165-174. doi: 10.1111/j.1469-8137.2004.01146.x

Popper, Z. A., Michel, G., Hervé C., Domozych, D. S., Willats, W. G. T., Tuohy, M. G., et al. (2011). Evolution and diversity of plant cell walls: from algae to angiosperms. Annu. Rev. Plant Biol. 62, 567590. doi: 10.1146/annurev-arplant042110-103809

Popper, Z. A., Sadler, I. H., and Fry, S. C. (2001). 3-O-Methyl-D-galactose residues in lycophyte primary cell walls. Phytochemistry 57, 711719. doi: 10.1016/S0031-9422(01) 00140-6

Popper, Z. A., and Tuohy, M. G. (2010). Beyond the green: understanding the evolutionary puzzle of plants and algal cell walls. Plant Physiol. 153, 373-383. doi: 10.1104/pp.110.158055

Pryer, K. M., Schneider, H., Smith, A. R., Cranfill, R., Wolf, P. G., Hunt, J. S., et al. (2001). Horsetails and ferns are a monophyletic group and the closest living relatives to seed plants. Nature 409, 618-622. doi: 10.1038/ 35054555

Pryer, K. M., Schuettpelz, E., Wolf, P. G., Schneider, H., Smith, A. R., and Cranfill, R. (2004). Phylogeny and evolution of ferns (monilophytes) with a focus on the early leptosporangiate divergences. Am. J. Bot. 91, 1582-1598. doi: 10.3732/ajb.91. 10.1582

Racusen, R. H. (2002). Early development in fern gametophytes: interpreting the transition to prothallial architecture in terms of coordinated photosynthate production and osmotic ion uptake. Ann.
Bot. 89, 227-240. doi: 10.1093/aob/ mcf032

Richmond, T., and Somerville, C. (2000). The cellulose synthase superfamily. Plant Physiol. 124, 495-498. doi: 10.1104/pp.124.2.495

Rutherford, G., Tanurdzic, M., Hasebe, M., and Banks, J. A. (2004). A systematic gene silencing method suitable for high throughput, reverse genetic analyses of gene function in fern gametophytes. $B M C$ Plant Biol. 4:6. doi: 10.1186/14712229-4-6

Salmi, M. L., Bushart, T. J., Stout, S. C., and Roux, S. J. (2005). Profile and analysis of gene expression changes during early development in germinating spores of Ceratopteris richardii. Plant Physiol. 138, 1734-1745. doi: 10.1104/pp. 105. 062851

Sarkar, P., Bosneaga, E., and Auer, M. (2009). Plant cell walls throughout evolution: towards a molecular understanding of their design principals. J. Exp. Bot. 60, 3615-3535. doi: 10.1093/jxb/erp245

Schedlbauer, M. D., and Klekowski, E. J. Jr. (1972). Antheridogen activity in the fern Ceratopteris thalictroides (L.) Brongn. Bot. J. Linn. Soc 65, 399-413. doi: 10.1111/j.10958339.1972.tb02280.x

Schneider, H., Schuettpelz, E., Pryer, K. M., Cranfill, R., Magallón, S., and Lupia, R. (2004). Ferns diversified in the shadow of angiosperms. Nature 428, 553-557. doi: 10.1038/nature02361

Schuettpelz, E., and Pryer, K. M. (2008). "Fern phylogeny," in Biology and Evolution of Ferns and Lycophytes, eds T. A. Ranker and C. H. Haufler (Cambridge, UK: Cambridge University Press), 395-416.

Silva, G. B., Ionashiro, M., Carrara, T. B., Crivellari, A. C., Tiné, M. A. S., Prado, J., etal. (2011). Cell wall polysaccharides from fern leaves: evidence for a mannan-rich type III cell wall in Adiantum rad dianum. Phytochemistry 72, 2353 2360. doi: 10.1016/j.phytochem. 2011.08.020

Sørensen, I., Domozych, D. S. and Willats, W. G. T. (2010) How have plant cell walls evolved? Plant Physiol. 153, 366-372. doi: 10.1104/pp.110.154427

Sørensen, I., Pedersen, H. L., and Willats, W. G. (2009). An array of possibilities for pectin. Carbohydr. Res. 344, 1872-1878. doi: 10.1016/j.carres.2008.12.008

Sørensen, I., Pettolino, F. A., Wilson, S. M., Doblin, M. S. Johansen, B., Bacic, A., et al. (2008).
Mixed-linkage $(1 \rightarrow 3),(1 \rightarrow 4)-\beta$-Dglucan is not unique to the Poales and is an abundant component of Equisetum arvense cell walls. Plant J. 54, 510-521. doi: 10.1111/j.1365313X.2008.03453.x

Spiro, M. D., and Knisely, K. I. (2008). Alternation of generations and experimental design: a guidedinquiry lab exploring the nature of the herl developmental mutant of Ceratopteris richardii (C-Fern). CBE Life Sci. Educ. 7, 82-88. doi: 10.1187/cbe.07-82-88

Stout, S. C., Clark, G. B., ArcherEvans, S., and Roux, S. J. (2003). Rapid and efficient suppression of gene expression in a single-cell model system, Ceratopteris richardii. Plant Physiol. 131, 1165-1168. doi: 10.1104/pp.016949

Szymanski, D. B., and Cosgrove, D. J. (2009). Dynamic coordination of cytoskeletal and cell wall systems during plant cell morphogenesis. Curr. Biol. 19, R800-R811. doi:10.1016/j.cub.2009.07.056

Tilney, L. G., Cooke, T. J., Connelly, P. S., and Tilney, M. S. (1990). The distribution of plasmodesmata and its relationship to morphogenesis in fern gametophytes. Development 110, 1209-1221. doi: 10.1016/j.cub.2009.07.056

Tuskan, G. A., Di Fazio, S., Jansson, S., Bohlmann, J., and Grigoriev, I. (2006). The genome of black cottonwood, Populus trichocarpa (Torr. \& Gray). Science 313, 1596-1604. doi: 10.1126/science. 1128691

Vaughn, K. C., Hickok, L. G., Warne, T. R., and Farrow, A. C. (1990). Structural analysis and inheritance of a clumped-chloroplast mutant in the fern Ceratopteris. J. Heredity 81, 146-151.

Vissenberg, K., Van Sandt, V., Fry, S. C., and Verbelen, J.-P. (2003). Xyloglucan endotransglucosylase action is high in the root elongation zone and in the trichoblasts of all vascular plants from Selaginella to Zea mays. J. Exp. Bot. 54, 335-344. doi: 10.1093/jxb/erg024

Warne, T. R., Vogelien, D. L., and Hickok, L. G. (1995). Analysis of genetically and physiologically complex traits using Ceratopteris: a case history of salt tolerance. Int. J. Plant Sci. 156, 374-384. doi: $10.1086 / 297259$

Weng, J.-K., Akiyama, T., Ralph, J., and Chapple, C. (2011). Independent recruitment of an $\mathrm{O}$ methyltransferase for syringyl lignin biosynthesis in Selaginella moellendorffii. Plant Cell 23, 2708-2724. doi: $10.1105 /$ tpc. 110.081547 
Weng, J.-K., Banks, J. A., and Chapple, C. (2008). Parallels in lignin biosynthesis. Commun. Integr. Biol. 1, 20-22. doi: 10.4161/cib. 1.1 .6466

Yang, Z.-L., Liu, H.-J., Wang, X.-R., and Zeng, Q.-Y. (2013). Molecular evolution and expression divergence of the Populus polygalacturonase supergene family shed light on the evolution of increasingly complex organs in plants. New Phytol. 197, 1353-1365. doi: 10.1111/nph.12107

Yin, Y., Huang, J., and Xu, Y. (2009). The cellulose synthase superfamily in fully sequenced plants and algae. $B M C$ Plant Biol. 9:99. doi: 10.1186/1471 2229-9-99

Zhao, Q., Wang, H., Yin, Y., Xu, Y., Chen, F., and Dixon, R. A. (2010). Syringyl lignin biosynthesis is directly regulated by a secondary cell wall master switch. Proc. Natl. Acad. Sci. U.S.A. 107, 14496-14501. doi: 10.1073/pnas.100 9170107

Conflict of Interest Statement: The authors declare that the research was conducted in the absence of any commercial or financial relationships that could be construed as a potentia conflict of interest.

Received: 26 April 2013; accepted: 29 August 2013; published online: 23 September 2013.

Citation: Leroux O, Eeckhout S, Viane RLL and Popper ZA (2013) Ceratopteris richardii (C-Fern): a model for investigating adaptive modification of vascular plant cell walls. Front. Plant Sci. 4:367. doi: 10.3389/fpls.2013.00367

This article was submitted to Plant Evolution and Development, a section of the journal Frontiers in Plant Science.

Copyright (c) 2013 Leroux, Eeckhout, Viane and Popper. This is an openaccess article distributed under the terms of the Creative Commons Attribution License (CC BY). The use, distribution or reproduction in other forums is permitted, provided the original author(s) or licensor are credited and that the original publication in this journal is cited, in accordance with accepted academic practice. No use, distribution or reproduction is permitted which does not comply with these terms. 